\title{
Influence of High-Pressure Die-Casting Second Stage Parameter on Structure Of AlSi9Cu3(Fe) Alloy
}

Łukasz Pałyga, Mateusz Stachowicz, Kazimierz Granat

Department of Foundry Engineering, Plastics and Automation, Wrocław University of Technology, Wybrzeże Wyspiańskiego 25, 50-370 Wrocław, Poland. E-mail: mateusz.stachowicz@pwr.edu.pl

In the paper, results of a research on influence of piston stroke rate on structures of $\mathrm{AISi9Cu3(Fe)} \mathrm{(EN} \mathrm{AB-46000}$ group) castings manufactured at constant intensification pressure of 290 bar are presented. Relation between piston speed $(0.3-2.3 \mathrm{~m} / \mathrm{s})$ and casting structure was evaluated after a series of trial high-pressure castings. The examinations were carried-out on properly prepared samples taken from the castings in places with the largest crosssection area. The effect of pouring rate was evaluated on the grounds of metallographic observations on a light microscope and a scanning electron microscope. It was found that larger grains of the very hard phase solidify at low piston speed between 0.3 and $0.75 \mathrm{~m} / \mathrm{s}$. Higher piston speed results in finer casting structure and in refinement of particles of intermetallic Fe-Mn phase, which is beneficial for usable properties of the castings.

Keywords: pressure die casting, structure, silumin, SEM, $2^{\text {nd }}$ injection stage

\section{References}

[1] PERZYK, M. (2004). Foundry engineering, issue 2, WNT, Warsaw, ISBN 83-204-2931-5 (in Polish).

[2] TSOUKALAS, V. D. (2008). Optimization of porosity formation in AlSi9Cu3 pressure die castings using genetic algorithm analysis. In: Materials and Design 29, pp. 2027-2033.

[3] POLOCZEK, Ł., DYBOWSKI, B., ŁUSZCZAK, M., KIEŁBUS, A. (2015). The microstructure of AlSi9iu3 Alloy after Different Stage of Liquid Metal Preparation. In: Archives of Foundry Engineering, Vol. 15, Special No. 1, pp. 89-92, Poland,

[4] KOZAKOWSKI, S. (2001). Badania odlewów. Technologie odlewnicze, typowe dla nich wady i metody ich ujawniania, Publisher Biuro Gamma, Warsaw, ISBN 83-87848-25-5 (in Polish).

[5] PAŁYGA, Ł., STACHOWICZ M., GRANAT, K. (2015). Effect of Selected Parameters of Pressure Die Casting on Quality of AlSi9Cu3 Castings. In: Archives of Foundry Engineering, Vol 15, No. 2, pp. 85-90, Poland.

[6] PAŁYGA, Ł. (2014). Analysis of the effect of controlling an automated stand for pressure pouring on quality of a back-seat bracket cast of the alloy EN AB 46000, Master's Thesis, Wrocław: Wrocław University of Technology. (in Polish),

[7] PAŁYGA, Ł., STACHOWICZ, M., GRANAT, K. (2015). Evaluation of 2D and 3D surface roughness of die casting from alloy AlSi9Cu3. In: Archives of Foundry Engineering, Vol. 15, Special No. 1, pp. 75-80, Poland.

[8] ORŁOWICZ, A.W., MRÓZ, M., TUPAJ, M., BETLEJ, J., PŁOSZAJ, F. (2009). Influence of refining process on the porosity of high pressure die casting alloy Al-Si. In: Archives of Foundry Engineering, Vol 9, No. 2, pp. 3540, Poland.

[9] HWANG, J.Y., DOTY, H.W., KAUFMAN, M.J. (2008). The effects of Mn addition on the microstructure and mechanical properities of Al-Si-Cu casting alloys. In: Materials Science and Engineering: A, Vol. 488, No. 1-2, pp. 496-504.

[10]SĘKOWSKI, K., PIASKOWSKI, J., WOJTOWICZ, Z. (1972). Atlas struktur znormalizowanych stopów odlewniczych., Wydawnictwo Naukowo-Techniczne, Warsaw, (in Polish).

[11]KUCHARIKOVÁ, L., TILLOVÁ, E., BELAN, J., UHRÍČIK, M. (2015). The Effect of Casting Technology on Fe Intermetallic Phases in Al-Si Cast Alloys. In: Manufacturing Technology, Vol. 15, No. 4, pp. $567-571$.

[12]TILlOVÁ, E., CHALUPOVÁ, M., HURTALOVÁ, L., ĎURINÍKOVÁ, E., (2011). Quality control of microstructure in recycled Al-Si cast alloys. In: Manufacturing Technology, Vol. 11, No. 11, pp. $70-76$.

[13]BELOV, N.A., ESKIN, D.G., AKSENOV, A.A. (2005). Multicomponent Phase Diagrams: Applications for Commercial Aluminum Alloys. Elsevier Science.

[14]http:/www.limatherm.com/img/fck/8910041/limatherm/File/Technical\%20information/Aluminium\%20specification.pdf. 